\title{
MANIFESTAÇÕES PATOLÓGICAS EM OBRAS DE ARTE ESPECIAIS: ESTUDO DE CASO DE UM VIADUTO RODOVIÁRIO EM SÃO LUIS-MA
}

\section{ARTIGO ORIGINAL}

PAIXÃO, Marcos Aurélio dos Santos ${ }^{1}$

BORBA, Fernando Vasconcelos ${ }^{2}$

ROCHA, Jorcelan Pereira da ${ }^{3}$

LIMA, Kennedy Bruno Araújo ${ }^{4}$

ARAÚJO, Wendel Melo Prudêncio de ${ }^{5}$

VIANA, Saymo Wendel De Jesus Peixoto ${ }^{6}$

FILHO, Leonardo Telles de Souza Pessoa ${ }^{7}$

PAIXÃO, Marcos Aurélio dos Santos. Et al. Manifestações patológicas em obras de arte especiais: Estudo de caso de um Viaduto Rodoviário em São Luis-Ma. Revista Científica Multidisciplinar Núcleo do Conhecimento. Ano 05, Ed. 04, Vol. 05, pp. 132-147. Abril de 2020. ISSN: 2448-0959, Link de acesso: https://www.nucleodoconhecimento.com.br/engenharia-civil/viadutorodoviario

${ }^{1}$ Especialista em Estruturas e Fundações, Engenheiro Civil, Técnico Em Edificações.

2 Mestrando em Estruturas e Construção Civil. Especialista em Estruturas e Fundações.

${ }^{3}$ Pós-Graduado em Infraestrutura de Transportes e Rodovias.

${ }^{4}$ Engenheiro Civil.

${ }^{5}$ Doutorando Engenharia dos Materiais. Mestre em Engenharia dos Materiais.

${ }^{6}$ Engenheiro Civil. Mestrando em Engenharia Civil.

7 Pós-Graduado em Infraestrutura de Transportes e Rodovias. 


\section{RESUMO}

A durabilidade e a integralidade das estruturas de concreto armado são alguns dos principais problemas a serem analisados atualmente pela engenharia civil, devido muitas estarem com suas estruturas oxidadas. Um dos fatores que ajuda na durabilidade da estrutura é a qualidade dos materiais utilizados na execução, bem como a manutenção preventiva nas estruturas, em especial as obras de arte especiais como pontes e viadutos. Este trabalho mostra algumas patologias analisadas em uma obra de arte especial, sendo um viaduto na zona urbana da cidade de São Luís - MA. Este viaduto faz parte do sistema viário da cidade, assim como outros viadutos e pontes da capital maranhense, possui patologias estruturais que podem levar à ruptura da estrutura se não forem reparadas a curto e médio prazo.

Palavras-chave: Patologias, viadutos, concreto armado.

\section{INTRODUÇÃO}

Por definição, obras de arte especiais são as obras que possuem um projeto específico para cada particularidade, ou seja, cada análise específica envolvendo as devidas etapas. As pontes e os viadutos são obras que são classificadas como obras de arte especiais que diferem entre si pelo obstáculo a ser vencido.

Segundo Oliveira (1999) as pontes e os viadutos são elementos de grande importância para o transporte de cargas rodoviárias e serem imprescindíveis para o escoamento da produção no Brasil. O número de pontes e viadutos no país é grande devido aos investimentos financeiros estrangeiros no setor da construção e a ampliação das rodovias brasileiras durante o período denominado de milagre econômico na década de 70 . O que torna estas obras fundamentais para o fluxo viário e da cadeia produtiva.

Todavia, a qualidade e a preocupação com as obras públicas não acompanharam a modernização e a industrialização corrente, fazendo com que as pontes e os viadutos 
brasileiros operem com a capacidade limite de estabilidade e segurança. Com isto, ocorreu com o passar dos anos, patologias além do normal nas estruturas.

Tal fato não é inédito, uma vez que se agrava à medida que a infraestrutura seja rodoviária, seja ferroviária "envelhece". Somando-se a este fato, não é cultura no Brasil realizar manutenções corretivas muito menos preventivas das pontes e viadutos existentes, o que permite o agravamento de inúmeras patologias nas estruturas de concreto armado e protendido.

As pontes de concreto armado no Brasil têm suas peculiaridades tais que foram em suas épocas de construção, recordes brasileiros no aspecto de construções de concreto armado. Assim, este trabalho consiste em uma análise das principais patologias causadas nas obras de arte especiais, tendo como referência um viaduto rodoviário na zona urbana da cidade de São Luís - MA, bem como as causas que originaram estas patologias e suas respectivas consequências na vida útil deste viaduto.

\section{REFERENCIAL TEÓRICO}

\subsection{PONTES E VIADUTOS}

Para El Debs e Takeya (2003), ponte é uma estrutura que pode ser formada de um ou mais materiais que tem por finalidade transpor talvegues ou qualquer tipo de superfície que esteja armazenando líquidos. Entretanto, o viaduto tem por finalidade cruzar um vale, grota ou uma via. Ou seja, são obras de engenharia que possuem o objetivo de dar continuidade a uma estrada (de grande ou pequeno porte), podendo ser classificadas em vista de múltiplos aspectos, como: seção transversal, obstáculo atravessado, quantidade de vãos, materiais, origem do tráfego e etc. Assim, quando as limitações não são formadas por água, as pontes são chamadas de viadutos (PFEIL, 1985).

Pfeil (1985) acrescenta que a denominação pontilhão é usada nos casos em que as pontes são constituídas por pequenos vãos (3,00 a 10,00 m) e pontes/viadutos para 
vãos maiores que 10,00 m. Assim, para Mason (1977) e Pfeil (1985) as pontes são divididas em: Superestrutura, Mesoestrutura e Infraestrutura, como exibido na Figura 1.

Figura 1 - Elementos constituintes das pontes

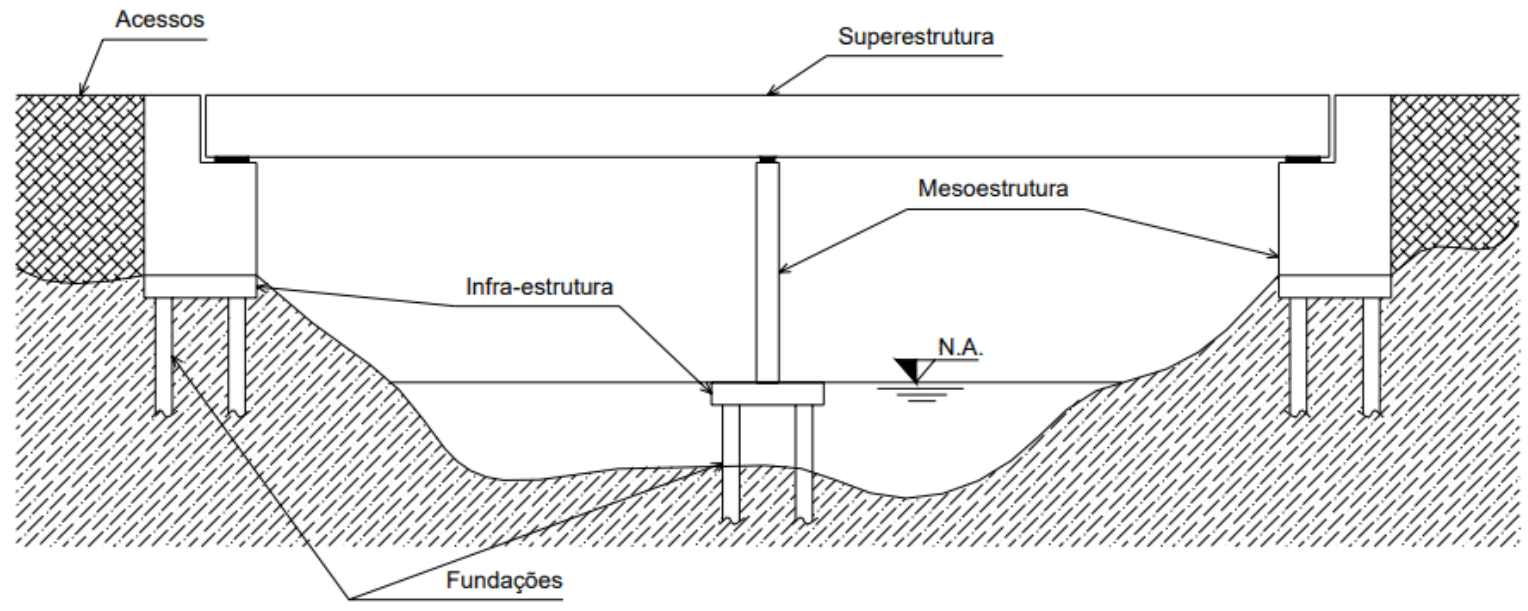

Fonte: Adaptada de Mason (1977)

Dessa maneira, a superestrutura é formada por transversinas e longarinas (elementos principais) e por tabuleiro (elemento secundário), este, é onde há atuação direta das cargas. A mesoestrutura é formada por pilares e encontros, tendo por objetivo receber os esforços da superestrutura e leva-los para a fundação. A infraestrutura pode ser composta por blocos, estacas e tubulões (fundação), e tem por finalidade transmitir os esforços para o solo (MASON, 1977; PFEIL, 1985).

\subsection{CLASSIFICAÇÕES DAS PONTES}

Dentre outros, Pfeil (1985) cita que as pontes/viadutos podem ser classificadas levando em consideração alguns aspectos importantes, como:

- Natureza do tráfego: rodoviárias, ferroviárias, passarelas, aeroviárias, canais e mistas (dois ou mais tipos de tráfegos);

- Material utilizado: madeira, alvenaria de tijolos ou pedra; aço; concreto simples; concreto armado; concreto protendido; mistas (dois ou mais tipos de materiais citados anteriormente); 
- Planimetria: retas (ortogonais e esconsas) e curvas;

- Altimetria: retas (horizontais ou em rampa) e curvas (convexo ou côncavo);

- Posição do tabuleiro: superior, intermediário e inferior;

- Seção transversal: laje (maciça ou vazada), viga (T ou I), celular; ou treliçada.

\section{PATOLOGIAS EM PONTES E VIADUTOS DE CONCRETO ARMADO}

Por estarem expostas a diversos tipos de ambientes, as obras de arte especiais, apesar de serem grandes estruturas, necessitam de uma manutenção constante em seus elementos. Assim, Andrade e Costa e Silva (2009) citam que não houve a devida preocupação com as obras de infraestrutura no decorrer dos anos, o que gerou diversos tipos de patologias, com diversas causas, ou seja, o envelhecimento das estruturas trás a ocorrência problemas.

Dessa maneira, Sartorti (2008) expõe alguns conceitos fundamentais em meio à ampliação do número de patologias apresentadas nas estruturais, estes são:

\section{a) Vida Útil}

É o intervalo de tempo em que uma estrutura permanece com suas propriedades físicas e químicas capazes de suportar as ações para qual foram projetadas, sendo que, se houver uma manutenção adequada, esse intervalo de tempo poderá ser ampliado. Um material chega ao limite da sua vida útil no período em que suas propriedades deterioram e o uso dessa estrutura torna-se insegura (SARTORTI, 2008).

b) Desempenho e Durabilidade

Sartorti (2008) explica que o desempenho de um material está relacionado diretamente com a atuação mecânico, acústico, estético, químico, entre outros. Sendo que, como atua uma estrutura durante sua vida útil, mostra a eficiência do trabalho realizado no período de projeto, construção e manutenção. Quando se fala de concreto simples/armado, o desempenho, na maioria das vezes, está ligado à resistência à compressão, o que expõe o desempenho mecânico do material. 
Já durabilidade de uma estrutura está ligada a manutenção, erros de projeto, erros de execução, entre outros. Assim, a diminuição da durabilidade ocasiona maiores trabalhos na recuperação estrutural e, consequentemente, custas mais altos (SARTORTI, 2008).

c) Manutenção e tipos de intervenção

De acordo com Andrade e Costa e Silva (2009), manutenção tem a finalidade manter as condições de funcionamento de um determinado objeto, aumento sua vida útil, ou seja, mesmo sem apresentar algum problema, a manutenção deve ser executada para manter o funcionamento e desemprenho adequado dos elementos estruturais. A manutenção está ligada com fatores econômicos ou a fatores técnicos, porquanto, as determinadas intervenções dependem do ambiente em que se encontra a estrutura e da dificuldade de execução dos serviços (LEONHARDT, 1979).

\section{ESTUDO DE CASO}

\subsection{INFORMAÇÕES GERAIS DO VIADUTO}

A obra de Arte Especial estudada foi um viaduto rodoviário composto de elementos estruturais mistos, situado na região central de São Luís. Trata-se de um viaduto relativamente antigo, que foi construído há quase três décadas.

Conhecido como "Viaduto Outeiro da Cruz" ou também como "Viaduto do Café", possui comprimento, de encontro a encontro, de aproximadamente 200 metros, interliga os bairros do Anil e João Paulo na Avenida João Pessoa, via de grande importância para o escoamento do intenso tráfego diário na capital maranhense. As figuras 2 e 3 mostram as vistas aérea e frontal deste viaduto. 


\section{MULTIDISCIPLINARY SCIENTIFIC JOURNAL

Figura 2 - Vista aérea do viaduto do café

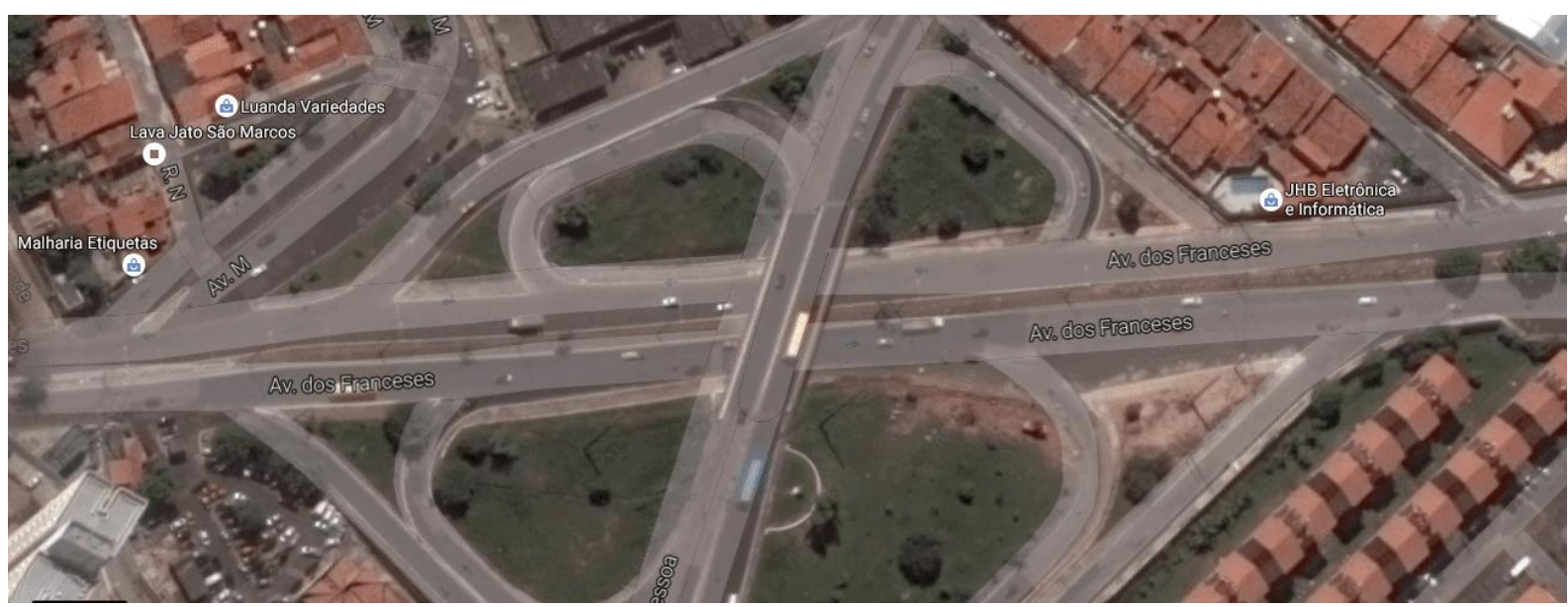

Fonte: Google Maps (2018)

Figura 3 - Vista frontal do viaduto do café

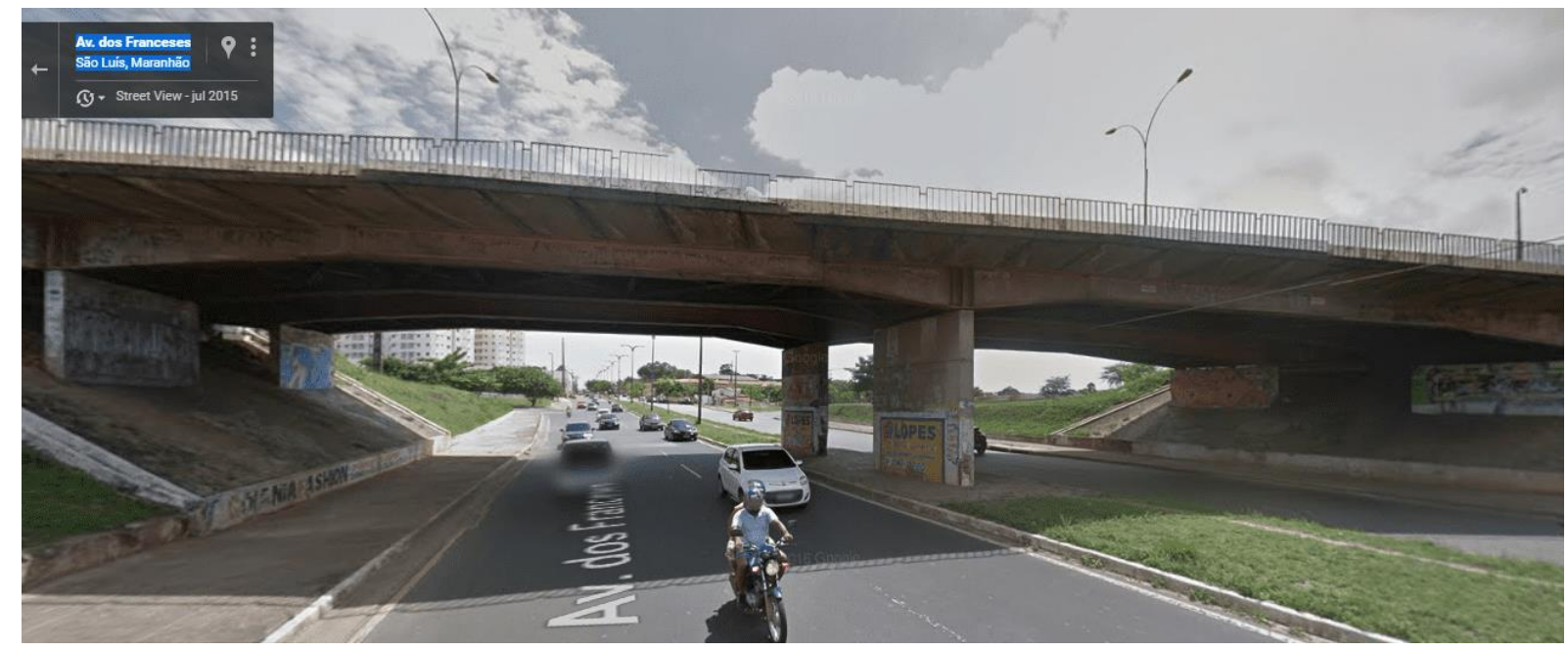

Fonte: Google Maps (2018)

No dia 21 de agosto de 2018 realizou-se visita em campo para fazer uma inspeção de cunho visual deste viaduto. Observou-se através da inspeção e levantamento de registros fotográficos que o mesmo está consideravelmente deteriorado em seus elementos estruturais (tabuleiro, vigas, encontros) devido a fatores que corroboram as teorias já citadas. 
Importante ressaltar que recentemente foi feito este ano, obras de alargamento da via abaixo deste viaduto, que é a Avenida dos Franceses, outra via de grande importância na viabilidade do tráfego intenso em São Luís. No entanto, obras de recuperação, restauração deste viaduto não foram realizadas pelos órgãos competentes.

\subsection{MESOESTRUTURA}

\subsubsection{PATOLOGIAS NOS ENCONTROS}

Foram observadas diversas patologias. A principal consiste na ausência do solo compactado usado para compor o encontro, bem como ausência das placas de paralelepípedo do encontro. A provável causa de ocorrer esta patologia é a má execução na compactação do solo e consequentemente houve lixiviação do mesmo ao longo do tempo com a ocorrência das chuvas, bem como vandalismo ao retirar as placas de paralelepípedo, visto que o assentamento destas placas foi mal executado. Observou-se também que há um grande acúmulo de lixo aonde não há solo compactado, surgimento de vegetação neste solo. As figuras 4,5 e 6 mostram o detalhe da patologia nos encontros do viaduto.

Estas patologias ocorreram em ambos os encontros do viaduto, o que compromete a estabilidade do mesmo. 


\section{MULTIDISCIPLINARY SCIENTIFIC JOURNAL

Figura 4 - Ausência de paralelepípedo e solo compactado no encontro lado direito

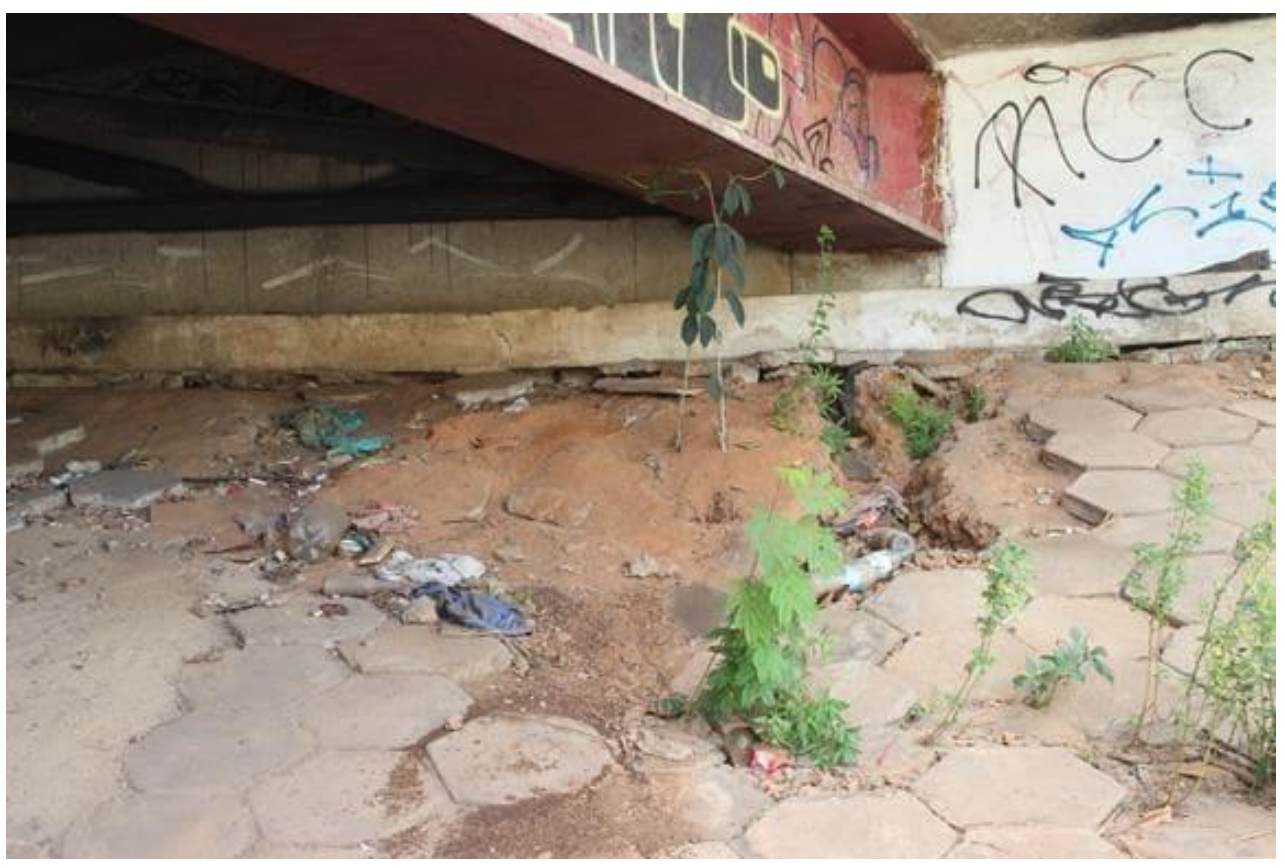

Fonte: Autores (2018)

Figura 5 - Ausência de paralelepípedo e solo compactado no encontro lado esquerdo

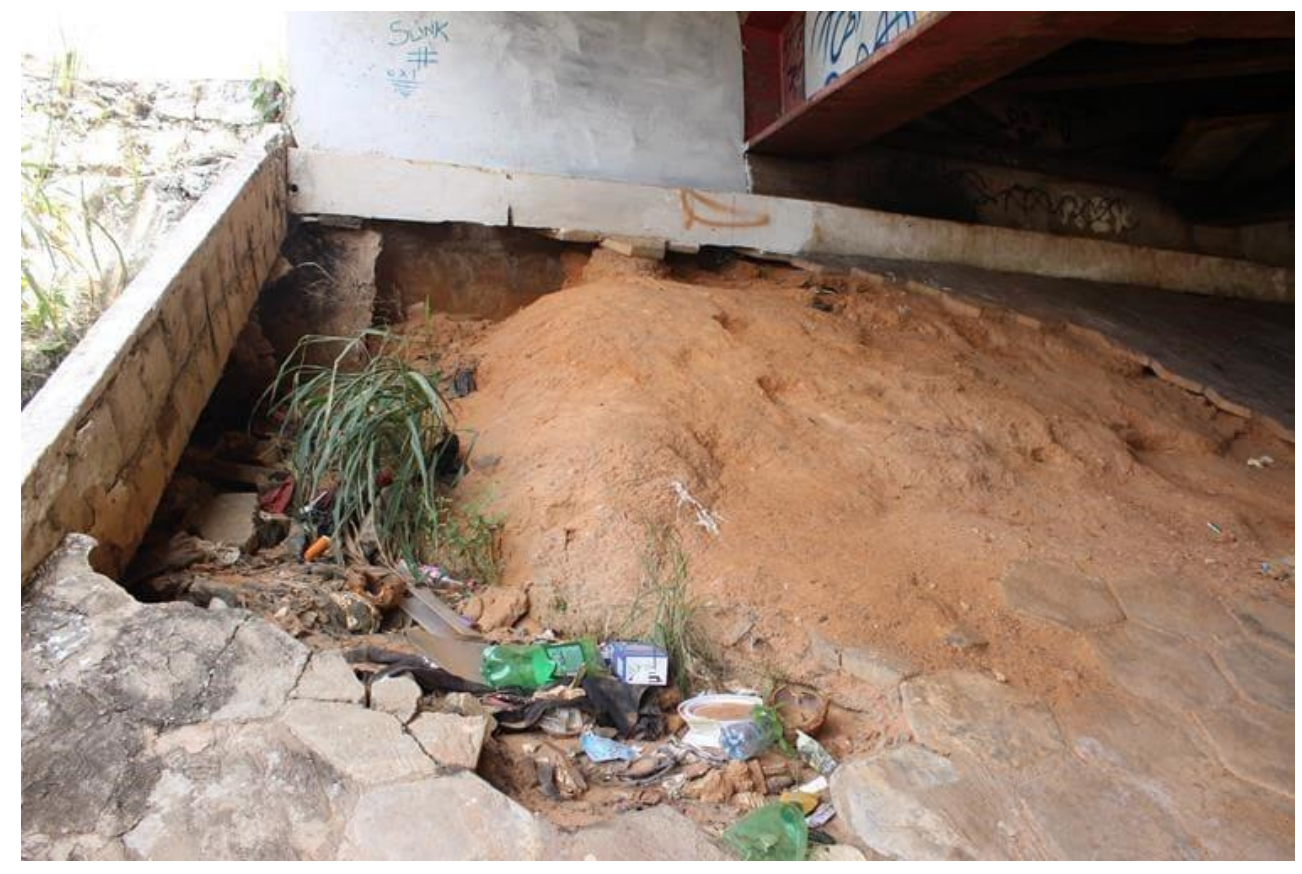

Fonte: Autores (2018) 
Figura 6 - Placas de paralelepípedo soltas no encontro lado direito

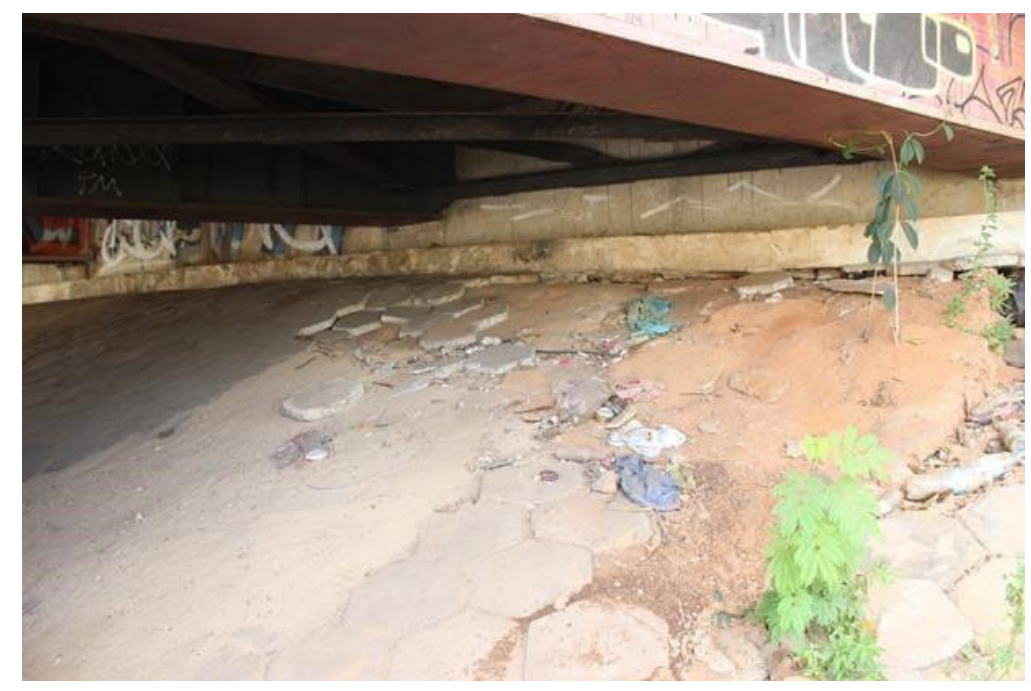

Fonte: Autores (2018)

Verificou-se também que a viga transversal, que compõe o topo dos encontros do viaduto também está comprometida. Há uma fissura no meio do vão da mesma, caracterizada como de flexão. A provável causa foi à solicitação da estrutura pelas cargas usuais. A viga não resistiu aos esforços e fissurou como mostrado na figura 7 .

Figura 7 - Fissuras de flexão na viga do topo do encontro lado direito

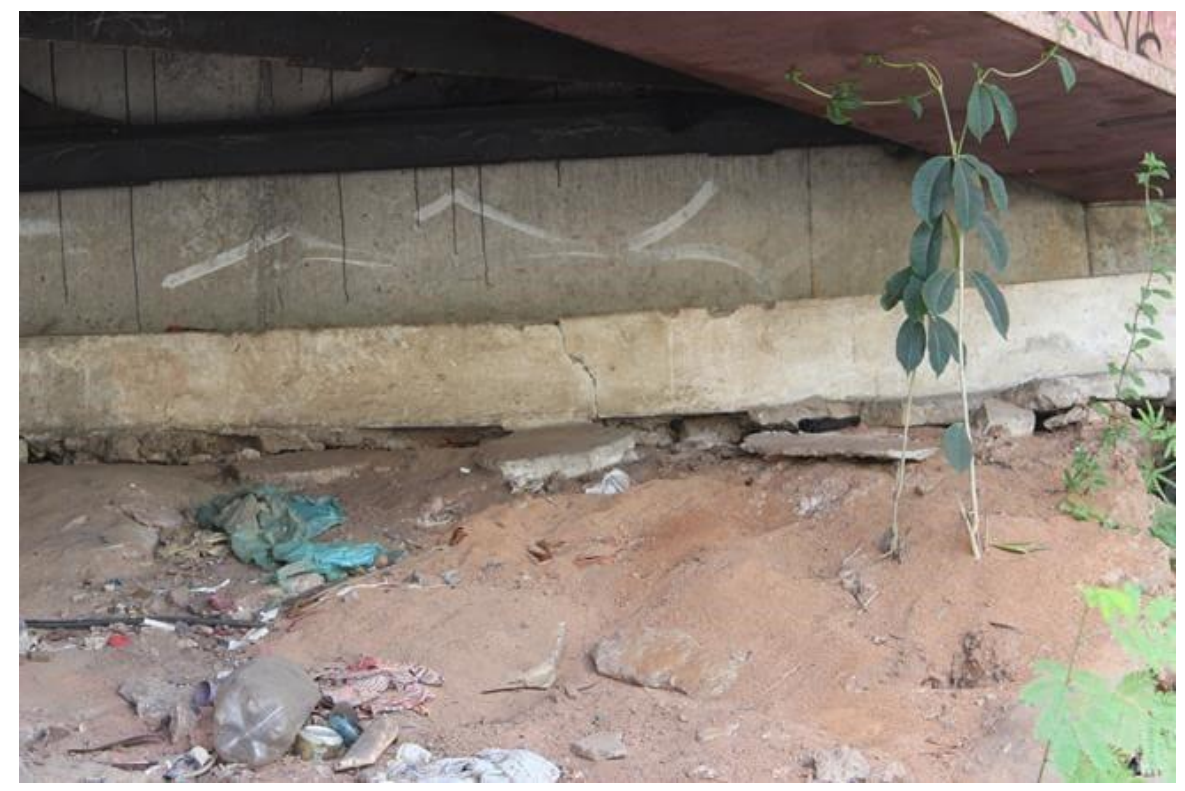

Fonte: Autores (2018)

RC: 49229

Disponível em: https://www.nucleodoconhecimento.com.br/engenharia-civil/viaduto-rodoviario 
No encontro do lado esquerdo do viaduto, há um preenchimento também com alvenaria estrutural, concreto e observou-se estaqueamento dentro deste preenchimento. Este estaqueamento tem como provável justificativa para ter sido utilizado, estabilizar e aumentar a interação solo-estrutura. O que não ocorre, pois o solo que deveria ser confinado foi carreado ao longo do tempo pela ação das chuvas, das intempéries. A figura 8 mostra este detalhe do estaqueamento no encontro. Observou-se também que a ligação desta parte do encontro com a superestrutura não é uma ligação monolítica.

Figura 8 - Estaqueamento no encontro sem a contenção do solo confinado

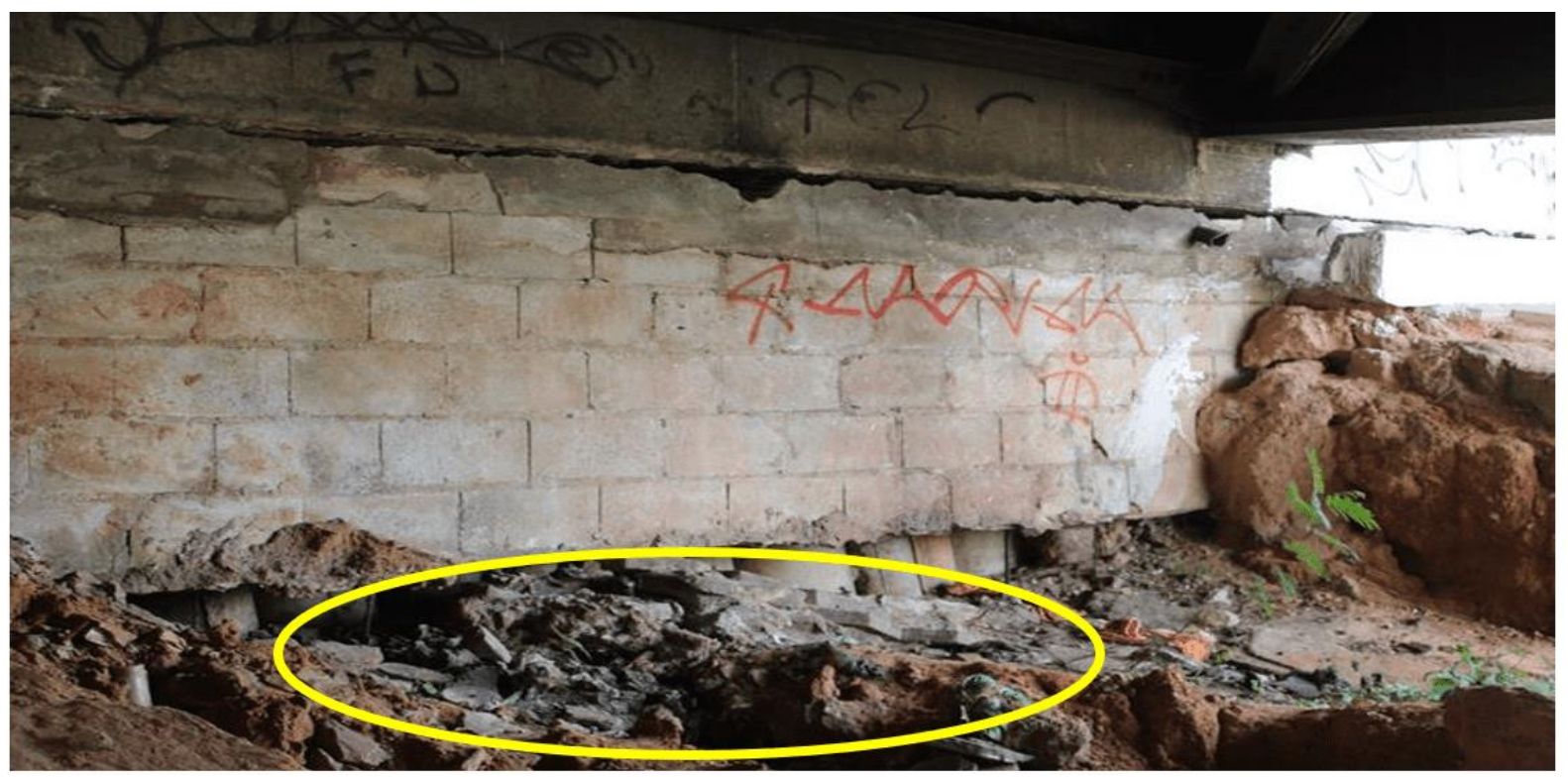

Fonte: Autores (2018)

\subsubsection{PATOLOGIAS NOS PILARES}

Os pilares deste viaduto, de ambos os lados, também se encontram deteriorados com diversas patologias. Nos pilares que ficam adjacentes aos encontros observaram-se manchas escuras e desplacamento do concreto causadas pela ação do fogo. A provável causa é o fogo feito por moradores de rua que dormem ao relento, usa o viaduto como abrigo fazendo fogueira tanto pra se aquecerem durante a noite, quanto para queimar lixo e entulhos. As figuras 9 e 10 mostram o detalhe da ação do fogo no pilar. 
Figura 9 - Ação do fogo na estrutura de concreto dos pilares

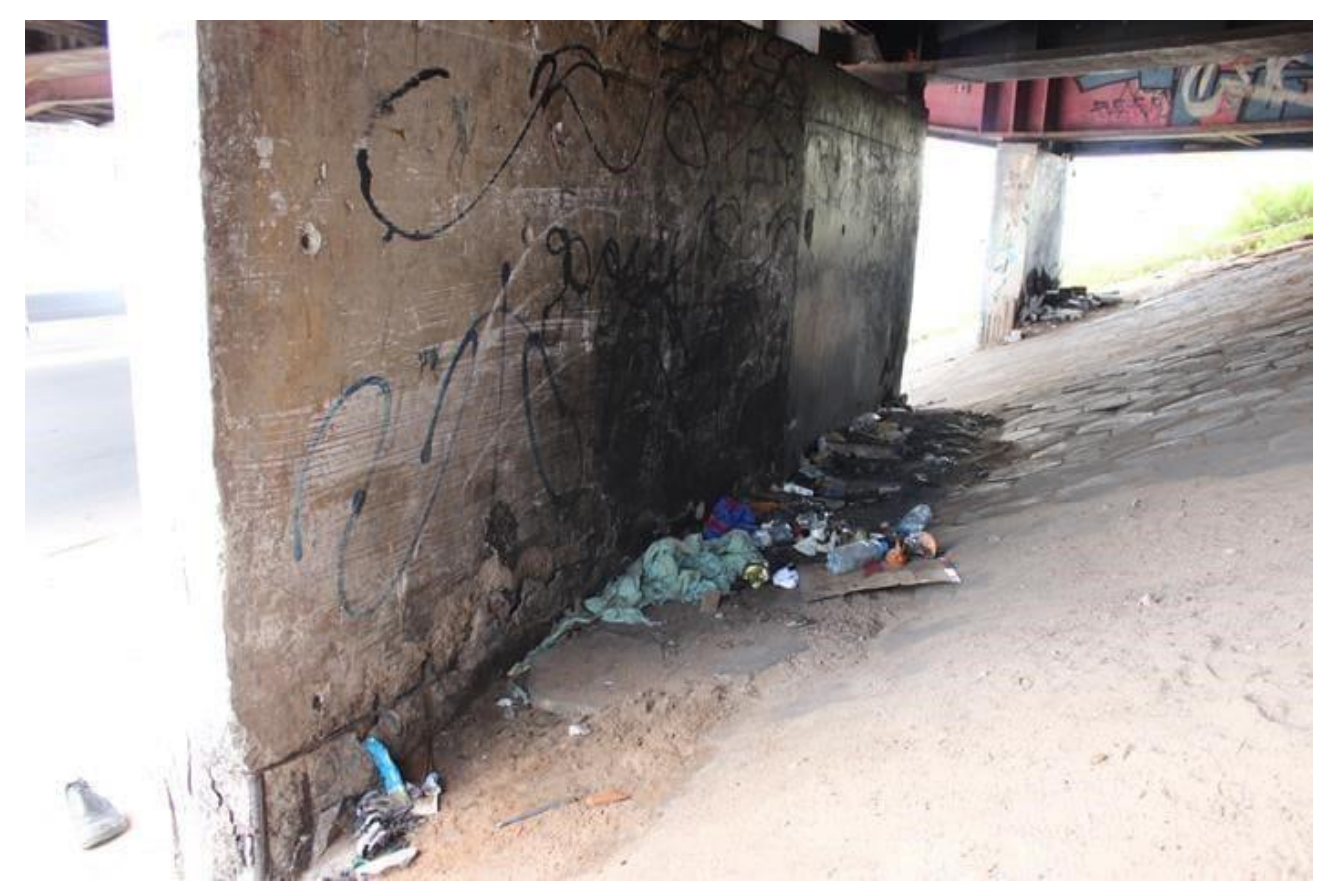

Fonte: Autores (2018)

Figura 10 - Ação do fogo causando o desplacamento nos pilares do viaduto

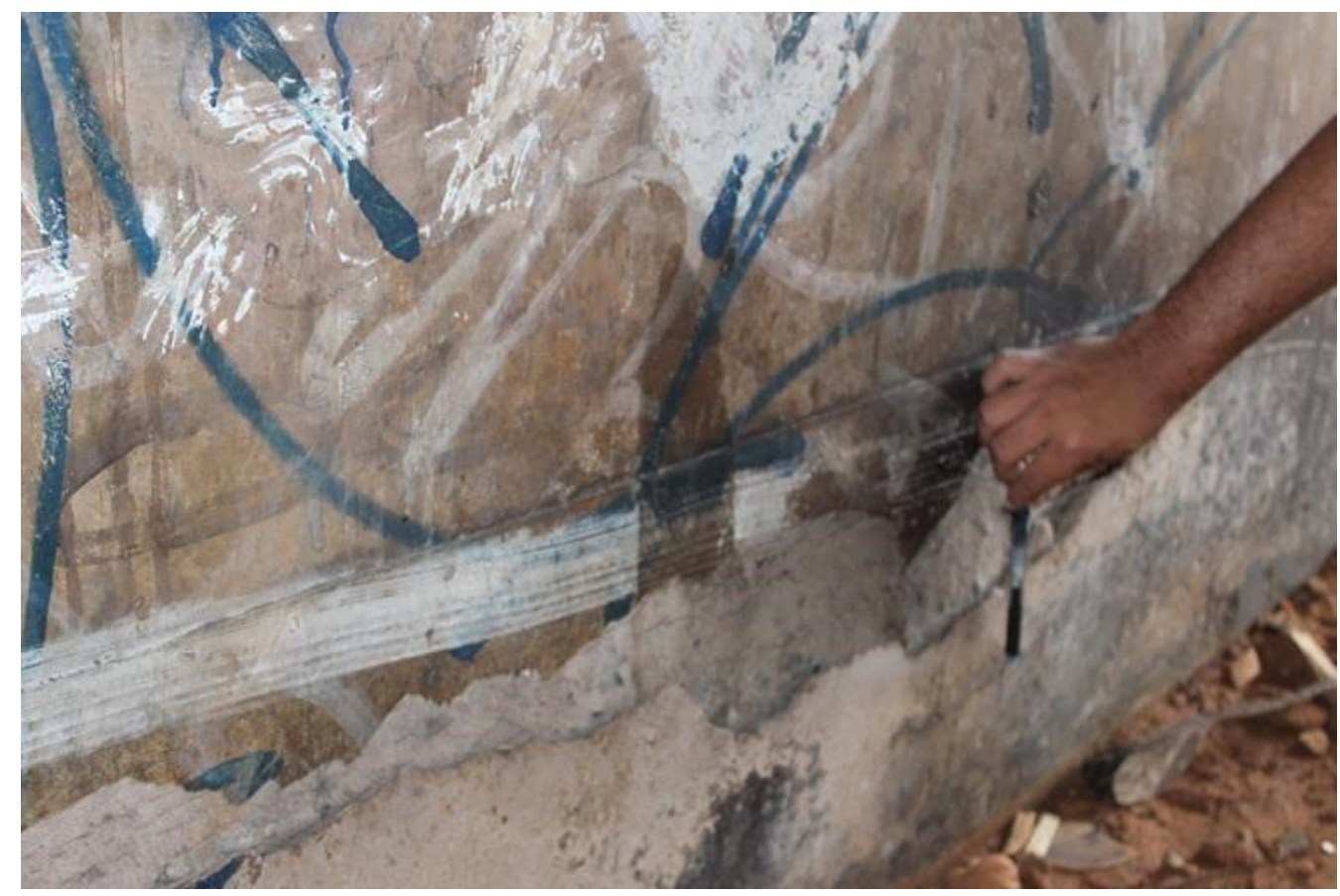

Fonte: Autores (2018)

RC: 49229

Disponível em: https://www.nucleodoconhecimento.com.br/engenharia-civil/viaduto-rodoviario 
Outra patologia importante observada, se não for a mais crítica, foram problemas de corrosão em todos os pilares do viaduto, onde as armaduras estão demasiadamente deterioradas por corrosão na base dos pilares. Alguns destes estão com corrosão em estágio avançado, que não há mais concreto que envolve as armaduras. Que por sua vez não há proteção alcalina por parte do concreto que envolve as armaduras, figura 11 e 12.

Figura 11 - Armaduras expostas na base dos pilares por causa da corrosão

[caption id="attachment_49283" align="aligncenter" width="504"]

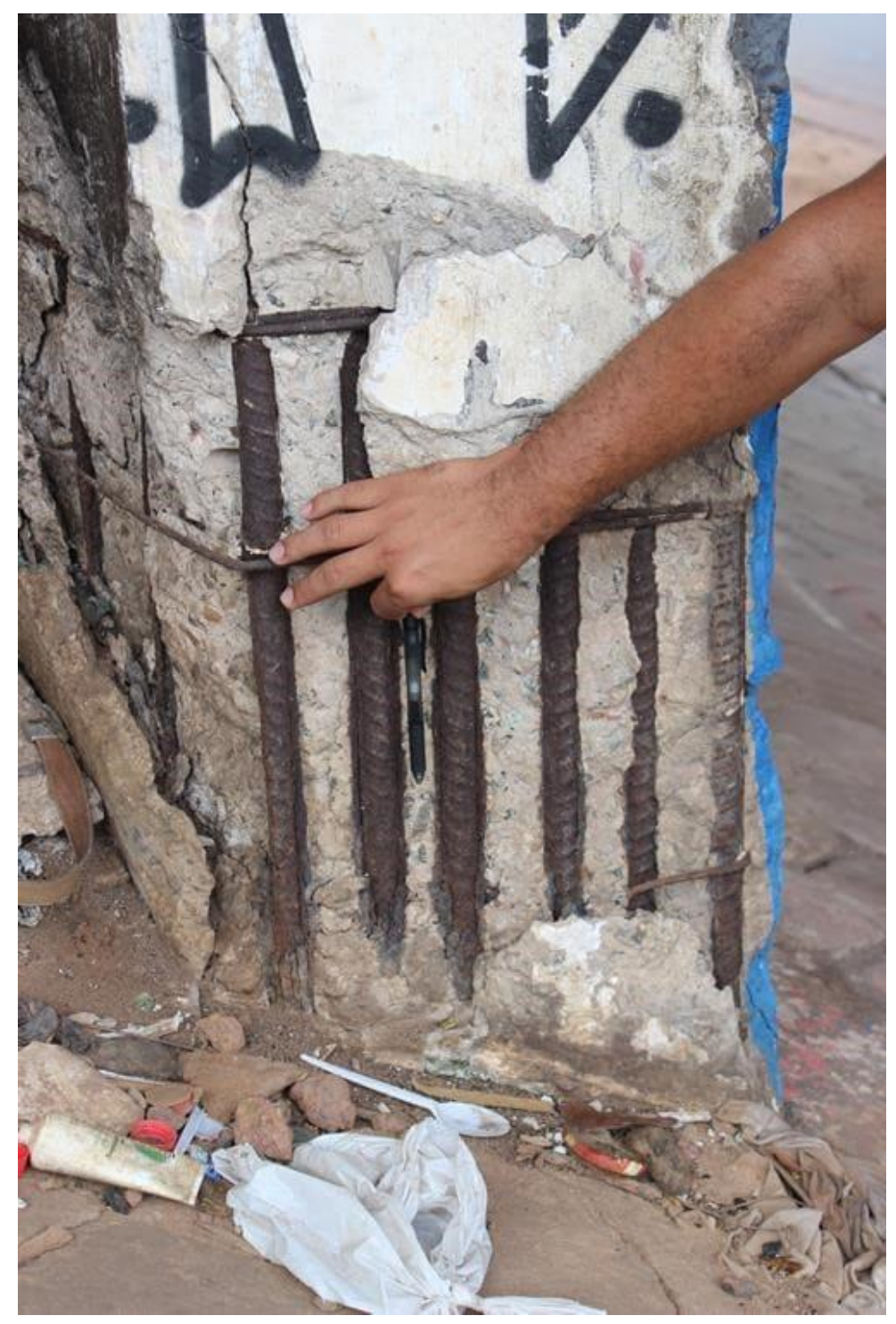

Fonte: Autores (2018) 
Figura 12 - Armaduras expostas na base dos pilares por causa da corrosão

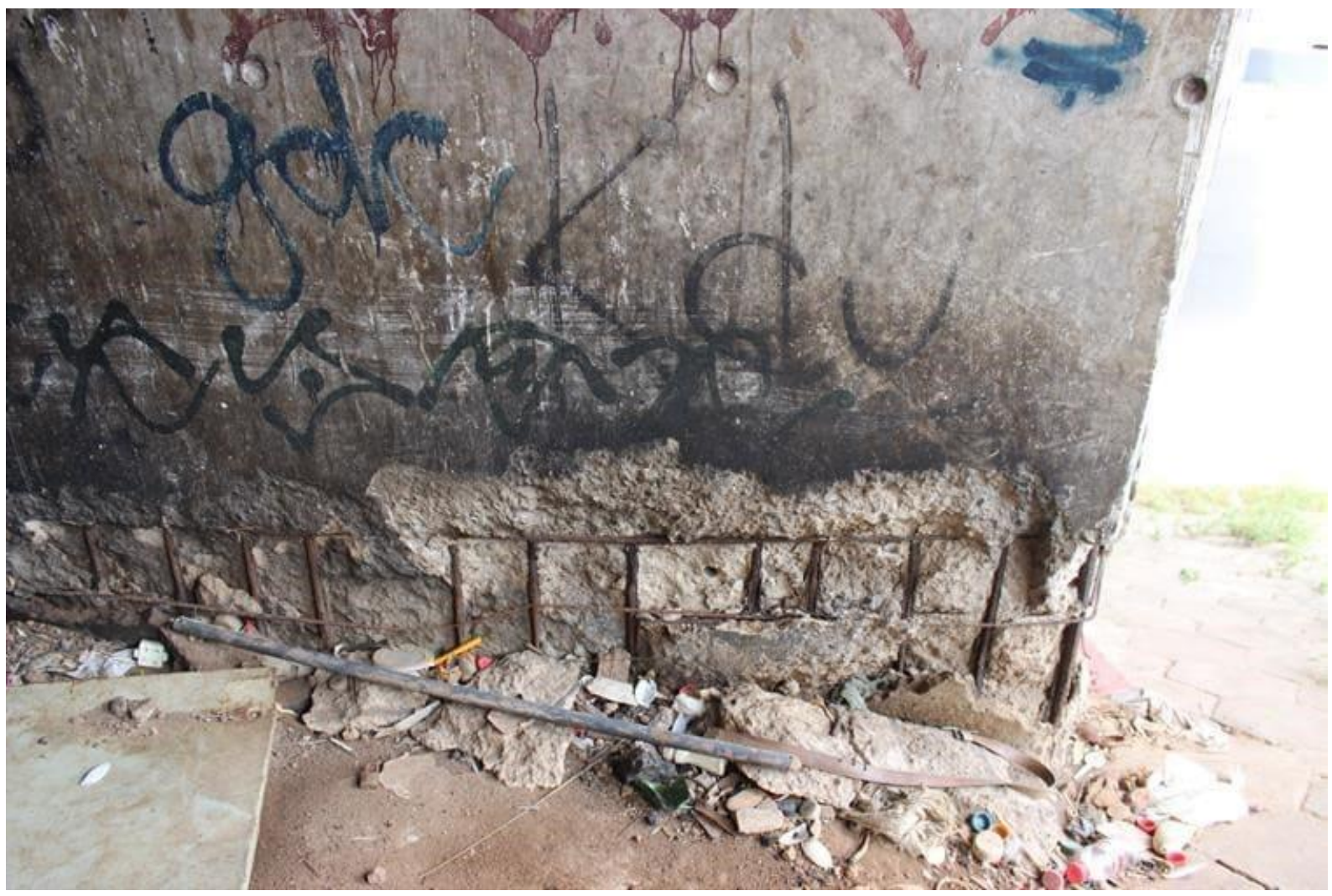

Fonte: Autores (2018)

\subsubsection{PATOLOGIAS NOS APARELHOS DE APOIO}

Os aparelhos de apoio deste viaduto são do tipo neoprene, comumente utilizados nas pontes e viadutos, por ser mais prático o fornecimento, assentamento e manutenção do mesmo, embora a manutenção seja precária nestes elementos. Observou-se nos aparelhos de apoio deste viaduto que alguns estão ressecados, com deslocamento considerável e trincas aparentes, evidenciando que já estão na sua capacidade limite de carga, seja pelas ações usuais do viaduto, seja pela má execução, bem como falta de manutenção dos mesmos. A figura 13 mostra as evidências nos aparelhos de apoio. 
Figura 13 - Aparelhos de apoio trincado e deformado

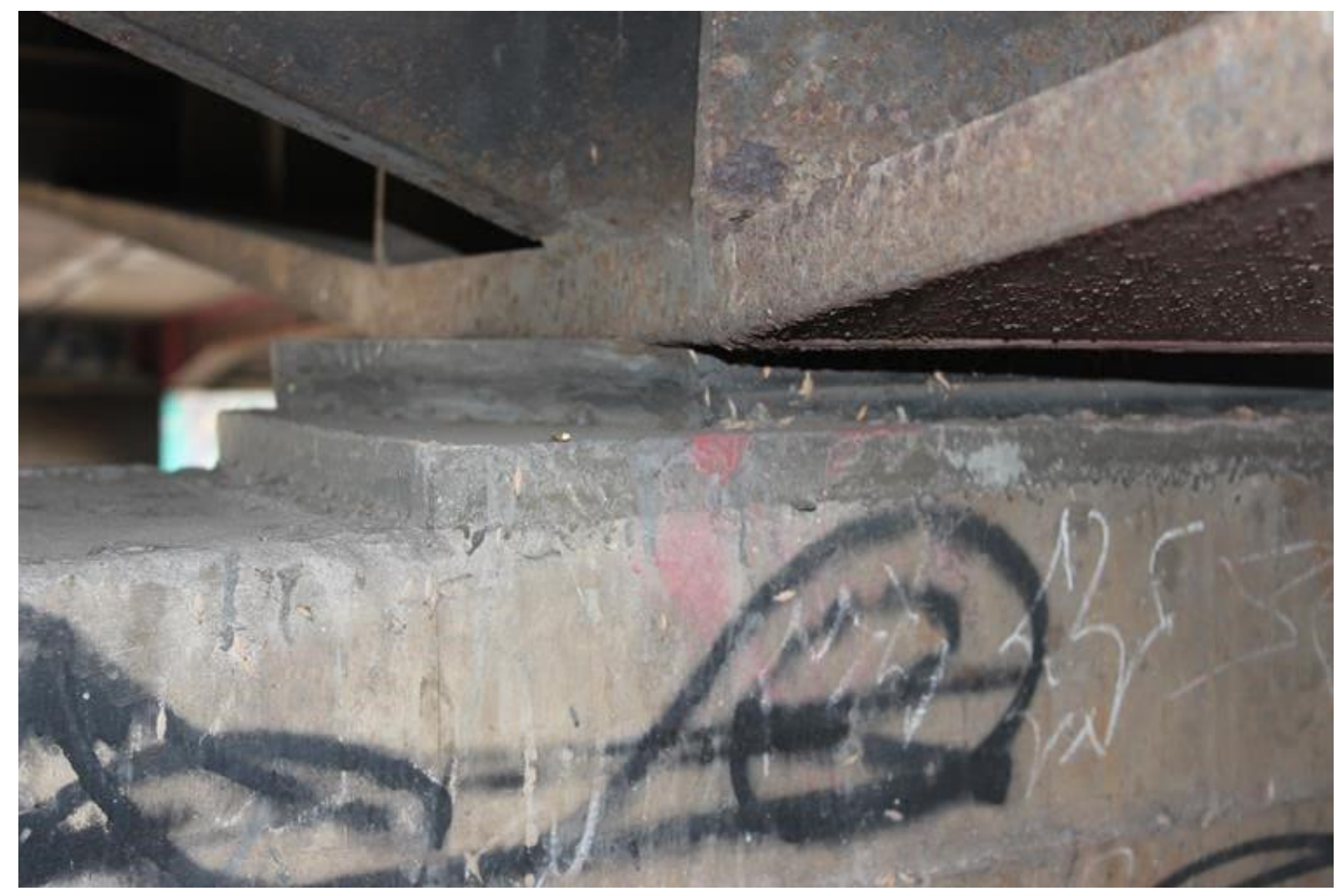

Fonte: Autores (2018)

\subsection{SUPERESTRUTURA}

$\mathrm{Na}$ superestrutura foram observadas patologias basicamente no tabuleiro. As longarinas e transversinas por serem de estruturas metálicas, não foram observadas consideráveis patologias, somente um processo inicial de corrosão.

\subsubsection{PATOLOGIAS NO TABULEIRO}

No tabuleiro deste viaduto, observando pela vista inferior foram identificadas patologias de lixiviação do concreto devido à infiltração e escoamento da água pluvial pelas juntas de encontro e dilatação do tabuleiro, conforme mostrado na figura 14 . Este problema de lixiviação no tabuleiro acarretou na exposição da armadura principal à flexão, deste tabuleiro. Esta patologia se não for reparada, irá degradar ainda mais o tabuleiro pela sua região inferior, podendo a armadura se perder com um processo 
de corrosão e carbonatação, devido à exposição aos agentes agressivos, tais como emissão de gases pelos veículos. Em todas as juntas ao longo do tabuleiro observouse esta patologia.

Figura 14 - Lixiviação do concreto acarretando armaduras expostas

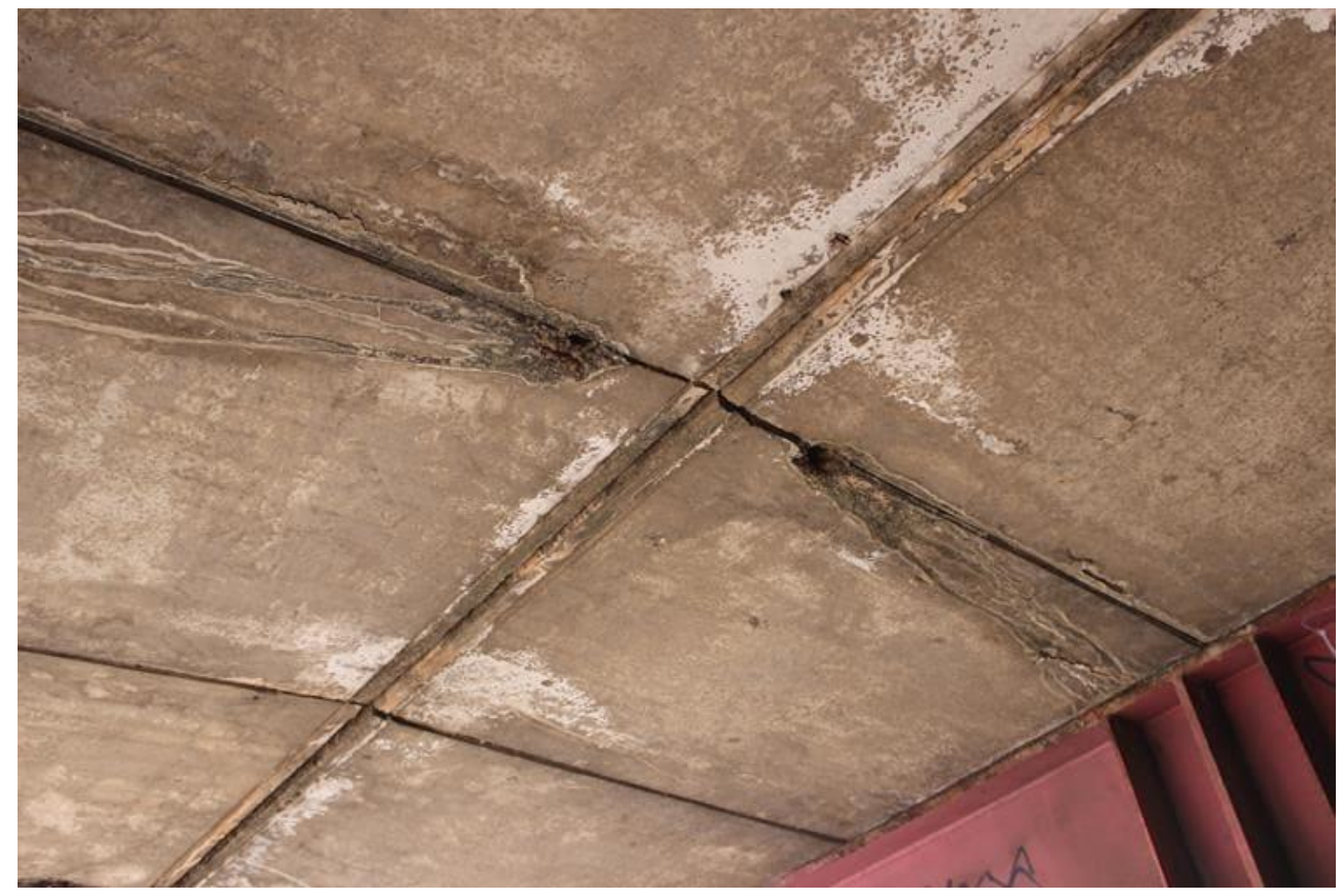

Fonte: Autores (2018)

\subsubsection{PATOLOGIAS NA PISTA DE ROLAMENTO}

$\mathrm{Na}$ pista de rolamento, observaram-se patologias no encontro do tabuleiro com o maciço. Trata-se de fissuras no pavimento asfáltico e a provável causa foi o deslocamento horizontal do tabuleiro do viaduto devido a ação das cargas móveis constantes, o que evidencia que não há manutenção preventiva do mesmo. A figura 15 mostra as patologias na pista de rolamento. Não foram identificadas em toda a pista de rolamento patologias ocasionadas por impactos de veículos. 
Figura 15 - Fissuras no pavimento asfáltico da pista de rolamento

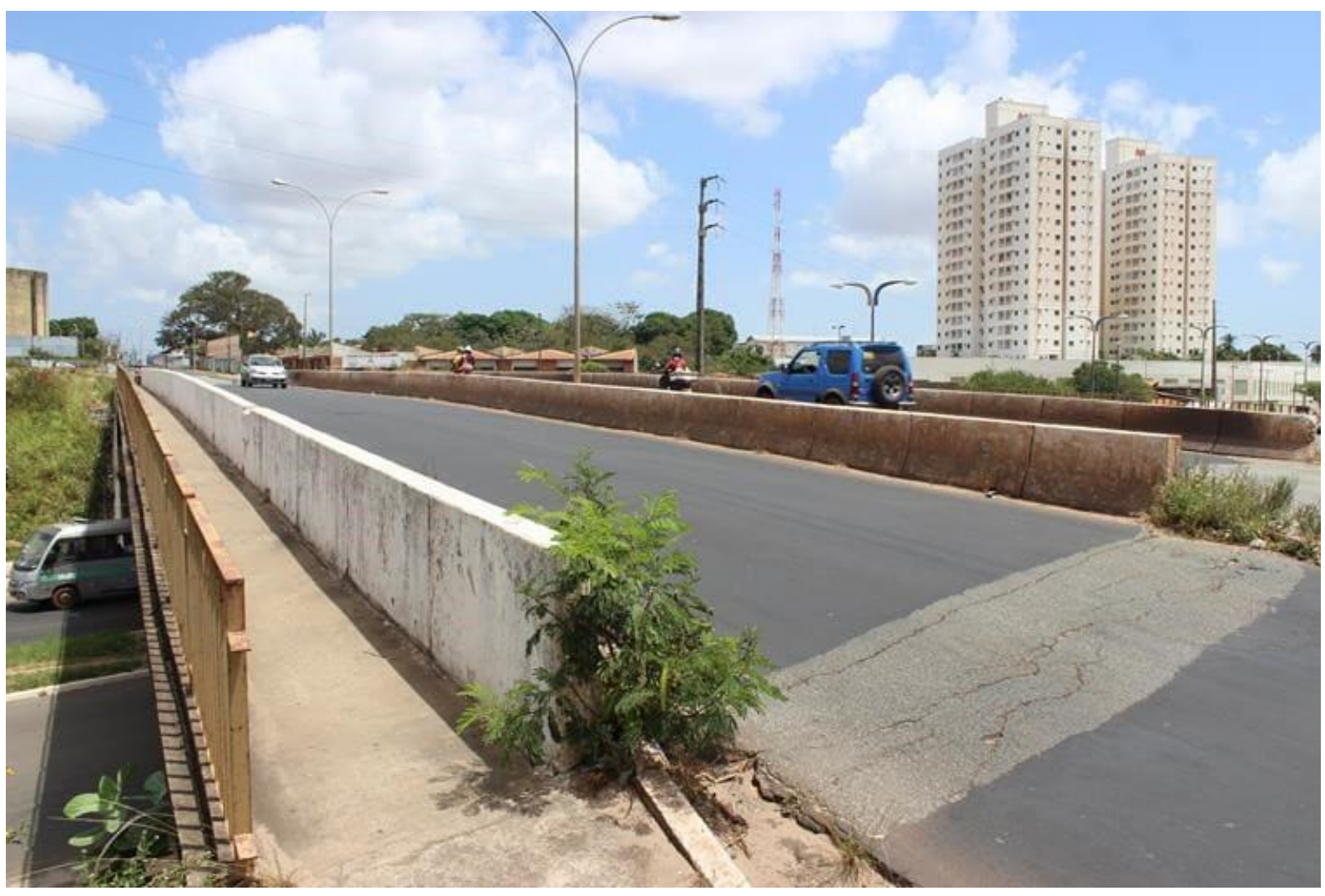

Fonte: Autores (2018)

Observou-se também que o meio fio na região dos encontros encontra-se em processo de fragmentação, pois não há solo como suporte sob a placa de concreto do meio-fio. Isto ocorre devido o solo ser carreado pelo escoamento da água, pois a drenagem pluvial estar deteriorada conforme mostrado na figura 16. Percebe-se também que foi feito somente uma pintura a base de cal sobre as armaduras expostas pelo processo de corrosão. A figura 17 mostra a passagem de pedestres com ruptura por não haver solo como suporte base da placa. 
Figura 16 - Canaleta de concreto da drenagem pluvial deteriorada por corrosão

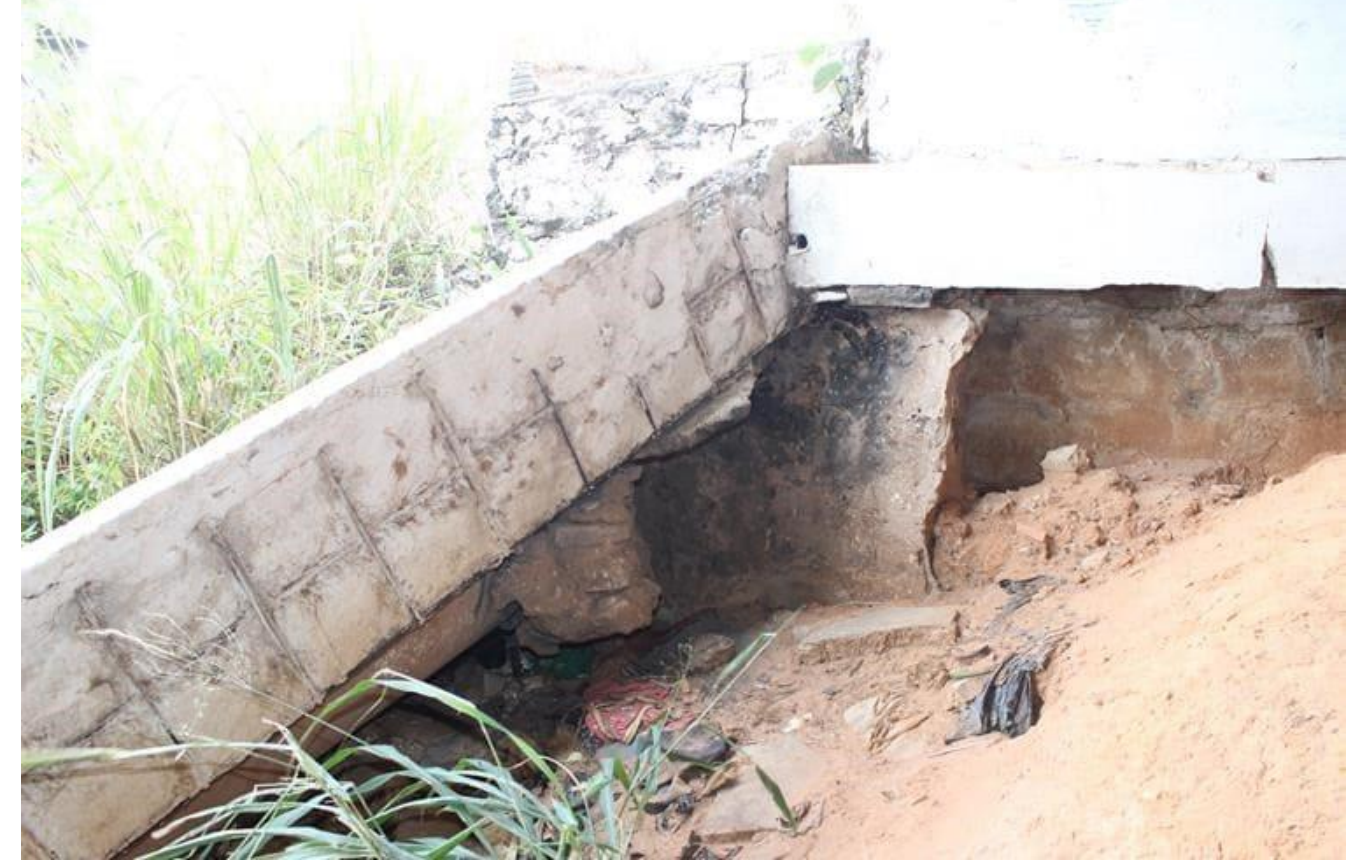

Fonte: Autores (2018)

Figura 17 - Calçada da passagem de pedestres com o concreto deteriorado

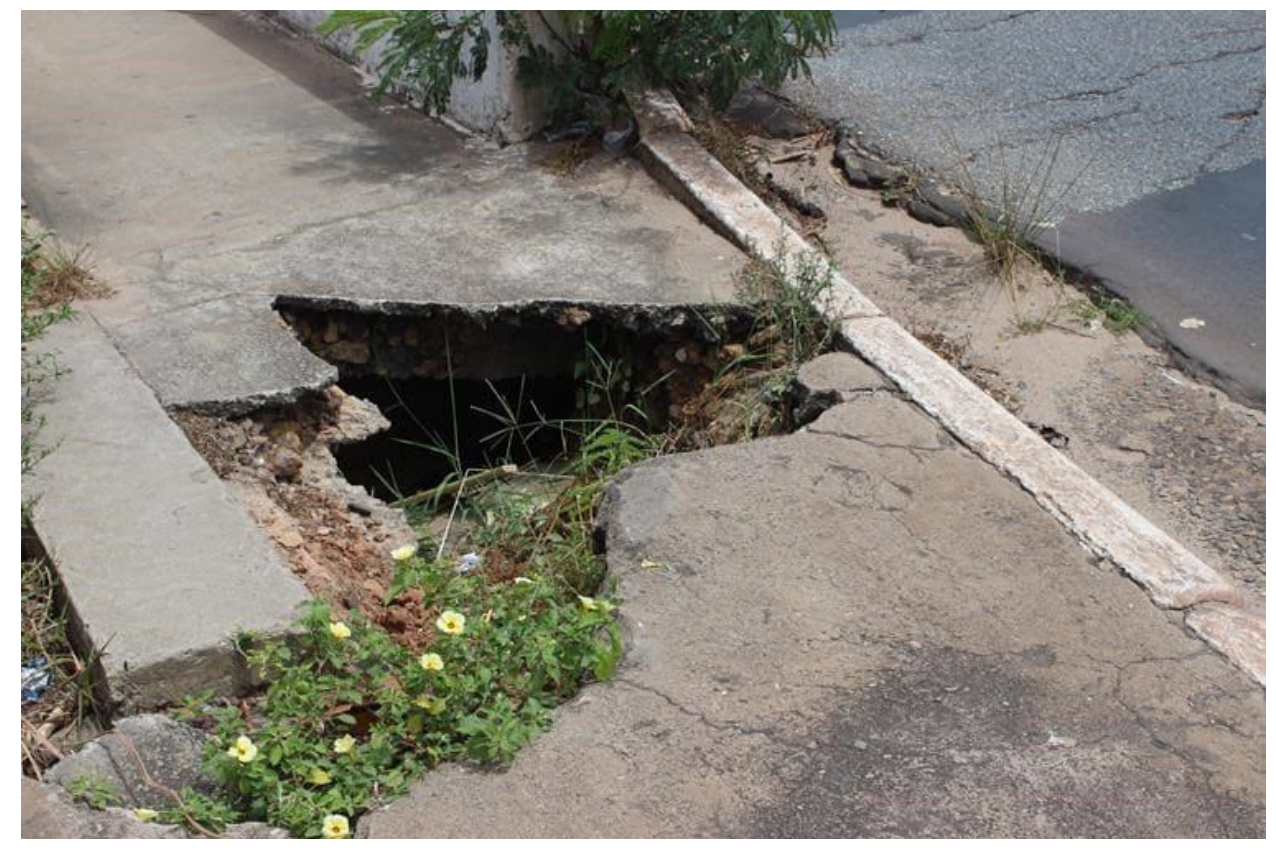

Fonte: Autores (2018) 
Foi observado que os bueiros que deveriam escoar as águas pluviais estão inutilizados, devido estarem obstruídos com lixo e entulhos e também pelo fato de que não se observou dispositivo de drenagem pluvial do bueiro para as vias de escoamento, conforme mostra a figura 18.

Figura 18 - Bueiro de drenagem pluvial obstruído com lixo

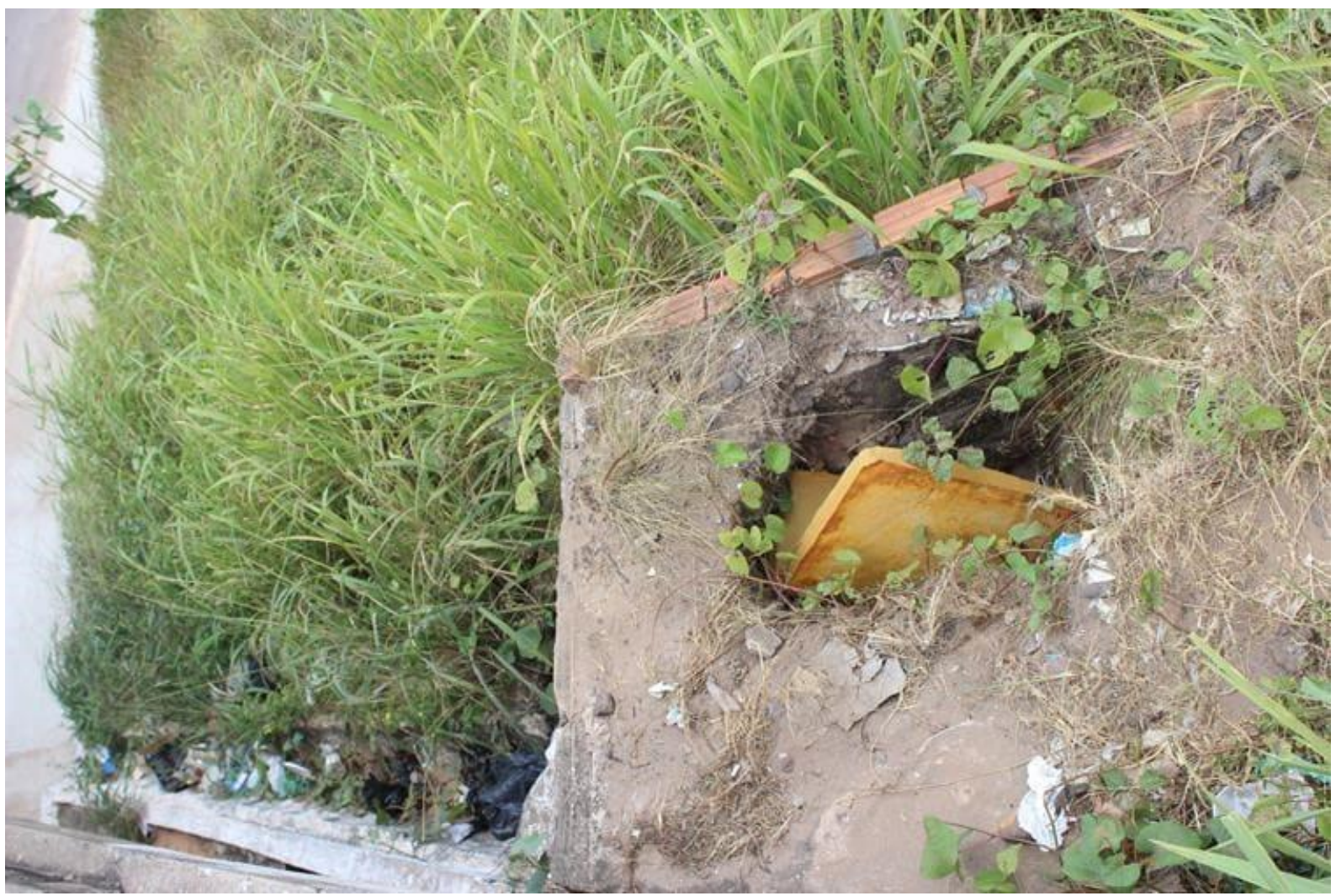

Fonte: Autores (2018)

\subsection{INFRAESTRUTURA}

A infraestrutura que corresponde à fundação do viaduto não foi analisada, devido não haver informações técnicas sobre o tipo de fundação a qual o mesmo foi construído, sendo um provável objeto de análise para trabalhos futuros. 


\section{CONCLUSÃO}

As obras de arte especiais como pontes e viadutos são responsáveis por garantir o fluxo intenso de veículos nas grandes cidades. Uma cidade, regiões metropolitanas não se viabilizam sem a construção de pontes, viadutos e passarelas com a finalidade de tornar o sistema viário mais eficaz.

Quanto à durabilidade, observa-se que as patologias examinadas afetam as estruturas inteiramente, e quando não se dispõem de inspeções e manutenções em pontes como esta estudada, o pequeno problema torna-se um extremo problema. É notório que as peças estruturais do viaduto em questão, estão com elevadas manifestações patológicas podendo assim, levar a estrutura à ruína. É de extrema importância frisar, que as grandes obras especiais no Brasil e no mundo, sofrem com esses problemas patológicos, tendo como responsáveis principais os órgãos competentes de fazer manutenção dessas estruturas. Assim, destaca-se como sugestões para trabalhos futuros:

- Analisar as técnicas de recuperação e reforço estrutural em campo neste viaduto a partir de registros fotográficos, quando forem realizadas pelos órgãos competentes acompanhando as etapas de execução;

- Verificar as possíveis manifestações patológicas na infraestrutura deste viaduto estudado;

- Realizar inspeção em campo como estudo de caso, manifestações patológicas em uma ponte rodoviária ou ferroviária de concreto armado ou protendido na região metropolitana da cidade de São Luís - MA.

\section{REFERÊNCIAS}

ANDRADE, Tibério; COSTA E SILVA, Angelo Just da. Considerações sobre durabilidade, patologia e manutenção das estruturas. Informe Técnico Tecomat. Recife, 2009. 
EI DEBS E TAKEYA. Introdução as Pontes de Concreto. Notas de Aula. Escola de Engenharia de São Carlos. São Carlos, São Paulo. 2003.

LEONHARDT, F. Construções de concreto: princípios básicos da construção de pontes de concreto. Rio de Janeiro: Interciência, 1979.

MASON, J. Pontes em Concreto Armado e Protendido. Rio de Janeiro: LTC, 1977.

OLIVEIRA, G. G. Importância na manutenção preventiva de pontes e viadutos do Rio Grande do Sul: Caracterização da tipologia das estruturas e levantamento de manifestações patológicas. Dissertação de mestrado. Universidade Federal do Rio Grande do Sul - UFRS. Porto Alegre, 1999.

PFEIL, W. Pontes em Concreto Armado v. 1 e v. 2. Rio de Janeiro: LTC, 1985.

SARTORTI, A. L. Identificação de patologias em pontes de vias urbanas e rurais no município de Campinas-SP. Dissertação de mestrado. Faculdade de Engenharia Civil da Universidade Estadual de Campinas. Campinas, 2008.

Enviado: Dezembro, 2019.

Aprovado: Abril, 2020. 